\title{
UNCLOS Part XV Dispute Settlement Mechanism and Its Potential Relevance to the Lithuania-Latvia Sea Boundary Delimitation
}

\author{
Ph.D. Dalia Višinskytè \\ Mykolas Romeris Law School, Lithuania \\ Geneva University Law School and Graduate Institute of \\ International Developmental Studies, Switzerland \\ dalia.visinskyte@mids.ch
}

\begin{abstract}
Settling of maritime boundary may be a challenging task. The Lithuanian-Latvian maritime border is still not settled and this legal uncertainty may lead to a maritime dispute. This article analyses what the international maritime boundary dispute settlement mechanisms are and how Lithuania and Latvia can use them if the dispute between the two countries arises.

Keywords: public international law, maritime boundary, international dispute settlement.

\section{Introduction}

Water is one of the world's largest and most important resources. The main instrument regulating the conduct of States in their uses of water is the United Nations Convention on the Law of the Sea (UNCLOS) that was signed in 1982 and entered into force in 1994. UNCLOS is nearly unique and it is one of the very rare types of treaties prescribing mandatory jurisdiction for its parties [2]. Even though the Convention is a fascinating international law instrument, in Lithuania it is rarely discussed about. It is true that having only 261 kilometers of coastline, Lithuania is not a powerful maritime State that has a great interest in maritime matters. However, the importance of UNCLOS is still largely undervalued. Already in 2010, it was estimated that the bed of the Baltic Sea around the presumable Lithuanian-Latvian border may contain up to
\end{abstract}


100 million tons of oil which was valued at over 70 billion US dollars [6]. However, these resources could not be extracted or further explored by any of the two States, because Lithuania and Latvia have never entirely agreed on the delimitation of the sea border between them.

The story behind is that on 9 July 1999 an agreement between the Republic of Latvia and the Republic of Lithuania on the delimitation of the territorial sea, exclusive economic zone and continental shelf in the Baltic sea was signed [15]. While Lithuania ratified the Agreement in October 1999, Latvia has never ratified it, which left the border unsettled. Lithuania, seeking guidance on the issue, has put the question regarding the exploration of the aforementioned oilfields before European Commission [6]. However, as it was explained by the Commission, regarding the question of possible joint search works of the oilfields, the delimitation of maritime zones falls entirely within the competence of the EU Member States [3]. Delimitation of the continental shelf between Lithuania and Latvia is thus governed by UNCLOS. Article 83 of the Convention sets out the rules and principles for delimiting the continental shelf between States with opposite or adjacent coasts and its paragraph 3 governs provisional arrangements pending final delimitation. The Commission also noted that if no agreement on delimitation can be reached within a reasonable period of time, Lithuania and Latvia shall resort to the dispute settlement procedures provided for in Part XV of UNCLOS.

Lithuania and Latvia have still not found an equitable solution for their maritime border delimitation, which makes resorting to the UNCLOS dispute settlement mechanism not completely unlikely. The goal of this article is to provide a brief overview of UNCLOS provisions regulating sea boundary delimitation, UNCLOS dispute settlement mechanism and the implications of these provisions to the current situation of Lithuania and Latvia.

\section{Sea boundary delimitation under UNCLOS}

Each coastal State possesses a continental shelf that comprises a seabed and subsoil of the submarine area. Its delimitation is regulated by Article 83 of the Convention, more precisely, its paragraph 1 states that " $\mathrm{t}]$ he delimitation of the continental shelf between States with opposite or adjacent coasts shall be effected by agreement on the basis of international law, as referred to in Article 38 of the Statute of the International Court of Justice, in order to achieve an equitable solution". Paragraph 3 of the same article sets out an interim regime that is supposed to lead to a peaceful settlement of the boundary.

Two obligations for the disputing States arise out of these provisions. First, "in a spirit of understanding and co-operation" pending a final delimitation they shall make effort to enter into "provisional arrangements of a practical nature". This obligation relates to the general principle of good faith enshrined in Article 300 of the Convention and imposes a duty to negotiate in good faith [7]. The Tribunal in Guyana-Suriname 
arbitration interpreted the phase "in a spirit of understanding and cooperation" as indicating "the drafters' intent to require of the parties a conciliatory approach to negotiations, pursuant to which they would be prepared to make concessions in the pursuit of a provisional arrangement" [7]. Making any concessions is usually not easy for States; therefore, any interim agreements are temporary and without prejudice to the final delimitation [13]. Second, pending the final delimitation agreement, the parties shall make every effort not to jeopardise or hamper the reaching of such agreement. It does not mean that all activities in the disputed area are prohibited. Pending the final agreement on delimitation, a joint exploration and exploitation of maritime resources could be an option.

In fact, this type of arrangement has been actively encouraged by international courts and tribunals. For example, The Tribunal in Eritrea/Yemen arbitration explicitly stated that the States "should give every consideration to the shared or joint or unitised exploitation of any such resources" [8]. The arbitral tribunal in Guyana-Suriname dispute further developed on the interpretation of the provision and drew a clear line between acts that lead to physical damage, such as oil and gas exploitation, and those that do not, such as seismic exploration. The former ones can only be executed by a common consent of the delimiting States [7].

The Parties are supposed to reach an agreement on delimitation "within a reasonable period of time" [13]. The exact meaning of this provision is not clear and it should be judged on case by case basis having considered the general length and intensity of the negotiations. When the parties, or at least one of them, decide that no agreement can be reached, two scenarios become possible. First, if in the given situation, the disputes of maritime delimitation are subject to optional exceptions under Article 298 (1)(a)(i) [13] and thus exempted from submission to the compulsory dispute settlement procedure under Section 2, they could still be submitted to the compulsory conciliation proceedings under Section 2 of Annex V of UNCLOS. Second, and a more likely scenario as most States have not made declarations of optional exceptions, the dispute would be subject to the compulsory procedures entailing binding decisions under Section 2 of Part XV of the Convention. Since neither Lithuania, nor Latvia have made any declarations under Article 298, the latter scenario would apply to their dispute.

\section{Dispute settlement mechanism under UNCLOS}

The spirit and essence of the UNCLOS dispute settlement mechanism is to provide all the possible opportunities to the disputing States to settle their disputes in a friendly manner and to use the compulsory methods only as the last resort. The means of dispute settlement are provided in Part XV of UNCLOS. The section is divided into three parts: general provisions, compulsory procedures entailing binding decisions and limitations and exceptions to applicability of Section 2. As the first two parts are the core of UNCLOS dispute settlement system, they will be discussed in turns in this section. 
Dalia Višinskytè. UNCLOS Part XV Dispute Settlement Mechanism and Its Potential

Relevance to the Lithuania-Latvia Sea Boundary Delimitation

\section{Voluntary dispute settlement mechanisms}

Article 279 containing a general obligation to settle disputes by peaceful means states that "states Parties shall settle any dispute between them concerning the interpretation or application of this Convention by peaceful means in accordance with Article 2, paragraph 3, of the Charter of the United Nations and, to this end, shall seek a solution by the means indicated in Article 33, paragraph 1, of the Charter."

There are several important aspects of this article. First, it strictly limits the scope of the dispute settlement provisions to the application and interpretation of the Convention. A question not related, or too remotely related to these issues, could not, in principle, be settled under the UNCLOS. Second, by introducing the Charter provisions into the Convention, UNCLOS broadens their application as this way the provisions extend to the parties to the Convention that are not Members of the United Nations [5]. For example, the State of Palestine, acceded to UNCLOS on 2 January 2015, and is a full party to the Convention; however, it remains a non-Member Observer State at the United Nations [12]. Third, Article 279 refers only to the means, but not Article 33 of the Charter as a whole. The reason for this is to avoid the confusion that the provision applies only to the disputes "the continuance of which is likely to endanger the maintenance of international peace and security". [5] The dispute settlement mechanism of UNCLOS applies to all disputes that satisfy the requirements set out in Part XV of the Convention, regardless of their magnitude.

Article 281 provides that the compulsory settlement procedures of the Convention apply only where a dispute between the States could not be reached by any other means agreed by them. Furthermore, Article 282 refers to general, regional or bilateral agreement and again reiterates that recourse to the UNCLOS dispute settlement mechanism should only be exercised if no binding solution could be achieved in any other agreed forum. Both of these provisions reflect the general spirit of the Convention, i.e. to try all the other available options for the settlement of the dispute. However, if at least one State party to the dispute satisfies itself that no suitable solution can be found by other means than the recourse to Section 2, it should, according to Article 283, initiate exchange of views "regarding its settlement by negotiation or other peaceful means". It is important to note that this provision does not create an actual obligation to negotiate. The exchange of views differs from negotiation in a sense that it concerns the question of how, procedurally, the dispute should be settled, while negotiation concerns the very substance of the dispute and is a mean to actually settle it. [11]

There are no requirements as to the form of such exchange and an overly formalistic view should not be taken. In fact, as the tribunal in Chagos Marine Protected Area correctly observed that, in practice, substantive negotiations are not neatly separated from exchanges of views on the preferred means of settling a dispute [9]. 
Dalia Višinskyte. UNCLOS Part XV Dispute Settlement Mechanism and Its Potential

Relevance to the Lithuania-Latvia Sea Boundary Delimitation

\section{Compulsory dispute settlement mechanisms}

Any decision rendered by a court or tribunal having jurisdiction under Section 2 is final and binding between the parties [13]. The "opening article" of the section entitled "compulsory procedures entailing binding decisions" once again reiterates that the compulsory settlement procedures of Section 2 apply only as the last resort, when no settlement has been reached by recourse to Section 1 . The part of the provision saying that the disputes shall be submitted "at the request of any party" is the core of it and of the whole UNCLOS dispute settlement mechanism. Under Article 286, parties to the Convention have a right to unilaterally seize dispute settlement procedures and at the same time they are bound by the obligation to be submitted to such procedure [11]. The provision also delimits the scope of a dispute that can be brought under for compulsory settlement entailing binding decisions. It must fall under a dispute "concerning interpretation or application of [the] Conventions and it must not fall within the scope of limitations and exceptions provided for in Section 3".

The following Article 287 is one of the most unique features of UNCLOS. It allows member States to choose a forum for dispute settlement and provides four options: the International Tribunal of the Law of the Sea, the International Court of Justice (ICJ), the Arbitral Tribunal Constituted under Annex VII or a special arbitral tribunal for specific types of disputes constituted in accordance with Annex VIII. Such flexibility of forum choice was required in order to achieve consensus on compulsory dispute settlement mechanisms [4]. It seems that it was less important which forum would decide the dispute; what mattered was to have a compulsory procedure with a binding outcome. The mechanism of Article 287 is built on the declarations made by States when joining the Convention or any time thereafter.

However, the declarations are not mandatory and in fact, the majority of States, parties to the Convention, have not made them. The declarations, when made, are deposited with the Secretary General of the United Nation and the copies are transmitted to the States parties [13]. The choice is not limited to one forum. The States can choose one, two, three or all four. They can enumerate them in order of preference, or, as done by Lithuania and Latvia, choose several without indicating any preference. By choosing several forums, States are increasing their chances that the other party has made the same choice [11].

In practice, there does not seem to be much difference whether the order of preference is indicated or not in the declarations in which several dispute settlement bodies are chosen. Yet, it would seem sensible for plaintiff to initiate proceedings before the body that is indicated as potential respondent's first choice [11].

It is also possible for the parties to express a "negative choice" that is to indicate which forum shall be excluded. For example, Cuba, Algeria or Guinea Bissau have indicated that they do not accept the jurisdiction of the ICJ. In case a State has not made any declaration, it is deemed that is has accepted the arbitration under Annex VII [13]. Where parties to the dispute have, through their declarations, accepted the same procedure, 
Dalia Višinskytė. UNCLOS Part XV Dispute Settlement Mechanism and Its Potential

Relevance to the Lithuania-Latvia Sea Boundary Delimitation

the dispute can only be submitted to that procedure, unless they otherwise agree [13]. However, in case the parties to the dispute have not chosen the same forum, the dispute must be submitted to Annex VII Arbitration, unless the parties otherwise agree [13].

Annex VII arbitration, therefore, is a "default option" that fills the gaps left where no choice has been made or where the choices made in the declarations do not match. While Annex VII is the most prevalent mode of dispute settlement under UNCLOS [11], it is doubtful whether it actually is the best option. It is an ad hoc type arbitration where the proceedings can be quite expensive, less predictable and not necessarily more flexible as both parties must agree on all the arbitrators, otherwise, unless the parties agree on a third party that would make the remaining appointments, it will be the president of ITLOS who appoint the arbitrators [1].

Finally, and paradoxically, one of the main features of UNCLOS success is its provisions on automatic and permissible exceptions respectively provided for in Section 3 of Part XV and more precisely, Articles 297 and 298. Not being naïve and seeking to ensure the highest possible number of contracting parties, the drafters of the Convention from the very beginning understood the need to exclude the most sensitive issues such as state sovereignty from the obligation to submit them to a procedure entailing a binding decision [5]. Any court or tribunal that has UNCLOS as its basis for jurisdiction, in principle, cannot decide on sovereignty issues. Furthermore, the so-called "mixed disputes" involving land and maritime delimitations also cannot be decided solely under UNCLOS. At the same time, the broad scope of limitations and exceptions has not only been praised but also vastly criticised. The tribunal in Southern Bluefin Tuna expressed that "UNCLOS falls significantly short of establishing a truly comprehensive jurisdiction entailing binding decisions" [10].

\section{The maritime boundary between Lithuania and Latvia}

Lithuania has deposited its declaration under Article 287 in 2003 and it reads as follows:

"[..] in accordance with paragraph 1 of Article 287 of the Convention, the Republic of Lithuania chooses the following means for the settlement of dispute concerning the interpretation or application of this Convention: a) The International Tribunal for the Law of the Sea established in accordance with Annex VI; b) The International Court of Justice." [14]

Latvia did the same in 2004 and its declaration is the following:

"[i]n accordance with paragraph 1 of the Article 287 of the United Nations Convention on the Law of the Sea the Republic of Latvia declares that it chooses the following means for the settlement of dispute concerning the interpretation or application of this Convention: 1) The International Tribunal for the Law of the Sea established in accordance with Annex VI of the Convention, 2) The International Court of Justice." [14] 
Dalia Višinskytė. UNCLOS Part XV Dispute Settlement Mechanism and Its Potential

Relevance to the Lithuania-Latvia Sea Boundary Delimitation

What is evident is that the only difference between the two declarations is the wording and there is no difference as to the substance. Both States have indicated that they accept the jurisdiction of ITLOS and the ICJ and neither has expressed any preference as to these forums; therefore, it would be for the State initiating the procedures to choose the forum. Furthermore, neither Lithuania, not Latvia have made declarations on optional exceptions under Article 298, which means that the questions of maritime boundary delimitation are not excluded.

Thus, it is clear that the two States have a broad range of tools provided by UNCLOS to set their maritime boundary, and in case it cannot be achieved by a mutual agreement, to settle their dispute. First, they shall seek a mutual agreement to find an equitable solution as provided for in Article 283 (1) of the Convention. In the meantime, they shall try to enter into practical provisional arrangements that are without prejudice to the final delimitation. Furthermore, both States shall abstain from any actions that could jeopardise or hamper the reaching of the final agreement. As interpreted by jurisprudence, this includes abstention from any actions that could a physical effect such as oil and gas exploration without the agreement of the other State [7].

The States shall continue seeking a solution for a "reasonable period of time" and in case at least one State decides that a solution has not been reached, it can unilaterally resort to the compulsory dispute settlement mechanisms under Section 2 of Part XV. Of course, by that time, a proper dispute must have crystalised.

First, Lithuania and Latvia shall exchange views on how the dispute should be settled. Having in mind close and friendly diplomatic relations between the two States, this hurdle is likely to be overcome easily.

Second, one of the States could invite another to submit the dispute to non-binding conciliation. While having a third-party intervention, in principle, may help to find a solution. However, keeping in mind that the States have signed the unratified maritime boundary delimitation treaty twenty years ago and therefore that the uncertainty has been lasting for two decades, it is likely that the States would skip this option and resort directly to obtain a final and binding decision. As mentioned, since the declarations of Lithuania and Latvia are nearly identical, the procedure-initiating State would be the one choosing whether to go to the ICJ or to ITLOS. It would be a new experience for both States as neither has ever had a case before ITLOS or the ICJ. It is very difficult to tell which option would be better. ITLOS is a relatively new tribunal with specialised jurisdiction, while the ICJ, being the successor of the Permanent Court of International Justice, is a long-standing court with general jurisdiction. Therefore, being aware that there is no evidence that the outcome of a case depends on the chosen forum, both reputable bodies would seem to be a solid choice [1]. 
Dalia Višinskytė. UNCLOS Part XV Dispute Settlement Mechanism and Its Potential Relevance to the Lithuania-Latvia Sea Boundary Delimitation

\section{Conclusion}

UNCLOS is a fascinating convention with an elaborate dispute settlement mechanism. Its insistence on finding an amicable solution through voluntary procedures and the existence of compulsory procedures at the same time, is the key of its success. Neither Lithuania, nor Latvia have yet had a case under UNCLOS; therefore, it is a very interesting time to witness how these two States will go about setting their maritime boundary. It is likely to be the first time that they will have to employ the procedures provided for in UNCLOS. The uncertainty already lasting for over two decades has nothing but a negative effect to the development of the two States as neither can get fully engaged into the exploration and exploitation of the natural resources lying in the disputed area without a consent of the other State. What is more, a quick and efficient settling of the maritime boundary and even of the dispute if it arises is crucial for good diplomatic relations between these two sister-States.

\section{UNCLOS XV daḷa: strīdu izšḳiršanas mehānisms un tā iespējamā saistība ar Lietuvas-Latvijas jūras robežas noteikšanu}

\section{Kopsavilkums}

Šis raksts sniedz ìsu pārskatu par UNCLOS noteikumiem, kas regulē jūras robežu noteikšanu, jūras strīdu izškiršanas mehānismu un šo noteikumu ietekmi uz pašreizējo Lietuvas un Latvijas jūras robežas stāvokli. Pārsteidzoši, ka Lietuva un Latvija nekad nav vienojušās par jūras robežas noteikšanu starp tām. Ir parakstîts Latvijas un Lietuvas līgums par teritoriālās jūras, ekskluzivās ekonomiskās zonas un kontinentālā šelfa robežu noteikšanu Baltijas jūrā. Lietuva ratificēja šo līgumu, bet Latvija to nekad netika ratificējusi. Tādējādi jūras robeža starp šīm divām valstīm joprojām nav noteikta.

UNCLOS būtība un gars liek domāt, ka šì konvencija sniedz visas iespējamās izdevības domstarpībās iesaistītajām valstīm izšḳirt domstarpības draudzīgā veidā un izmantot piespiedu metodes tikai kā pēdējo iespēju. UNCLOS strīdu izškiriršanas mehānismus var iedalīt brīvprātīgos un piespiedu. Jūras robežas mierīga noregulēšana ir galvenais jūras strīdu izšḳiršanas mehānisms. Puses ved sarunas labā ticībā un cenšas rast draudzīgu risinājumu. Lai panāktu vienprātību par piespiedu strīdu izškirišanas mehānismiem, nepieciešama strīda izškirišanas vietas izvēles elastība jūras strīdu izšḳiršanai.

Gan Lietuva, gan Latvija ir norādijjušas, ka tās piekrīt Starptautiskā Jūras tiesību tribunāla un Starptautiskās Tiesas jurisdikcijai, un neviena no valstīm nav devusi priekšroku kādai no šīm strīdu izšķiršanas vietām, tāpēc valstij, kas ierosina procedūras, būtu jāizvēlas strīda izšḳirš̌anas vieta. 
Dalia Višinskytė. UNCLOS Part XV Dispute Settlement Mechanism and Its Potential Relevance to the Lithuania-Latvia Sea Boundary Delimitation

Šì raksta autore iesaka, pirmkārt, abām valstīm censties panākt savstarpēju vienošanos, lai rastu taisnīgu risinājumu. Tajā pat laikā tām jāmēgeina vienoties par praktisku pagaidu kārtību, kas neierobežo galīgo robežu noteikšanu. Turklāt abām valstīm jāatturas no jebkādām darbībām, kas varētu apdraudēt vai kavēt galīgās vienošanās panākšanu. Tomēr, ja šāda strīdu izškirš̌ana neizdodas, valstis atkarībā no to vēlmēm var izvēlēties izšḳirt jūras strīdu vai nu Starptautiskajā Jūras tiesību tribunālā vai Starptautiskajā tiesā.

Atslēgvārdi: starptautiskās tiesības, jūras robeža, robežstrīds, starptautisko strīdu izškiriršana.

\section{References}

1. Boyle, A. 2014. UNCLOS Dispute Settlement and the Uses and Abuses of Part XV, 47 Rev. BDI 182 p. 203; UNCLOS, Annex VII, Article 3 (e).

2. Another treaty containing mandatory jurisdiction is the WTO agreement.

3. Answer given by Mr. Vella on behalf of the European Commission on 30 September 2015 (question refence E-010582/2015).

4. Klein, N. 2005. Dispute Settlement in the UN Convention on the Law of the Sea, CUP, p. 51.

5. Nordquist, M. H., Rosenne S. \& Sohn, L. B. 1989. United Nations Convention on the Law of the Sea 1982. A Commentary, Vol. V. Dordrecht, M. Nijhoff Publ., 18.

6. Parliamentary question E-010582-15 posed on 30 June 2015 at the European Parliament.

7. PCA Arbitration Guyana-Suriname, Award, 17 September 2007, para 461.

8. PCA Arbitration Eritrea / Yemen II, Award, 17 December, 1999, para 86.

9. PCA Arbitration Award Chagos Marine Protected Area (The Republic of Mauritius and The United Kingdom), Award, 18 March 2015.

10. PCA Southern Bluefin Tuna Case (Australia and New Zealand v. Japan). Jurisdiction and Admissibility, Award of 4 August 2000 RIAAXXIII, 1, para. 62.

11. Proelss, A., 2015. 1834; PCA Arbitration Award Arctic Sunrise (The Netherlands v Russia), Award, 14 August 2015, para 151.

12. Status granted by resolution A/RES/67/19 of 29 November 2012.

13. UNCLOS.

14. United Nations Treaty Collection [accessed on 22 December 2019], https://reaties.un.org/Pages/ ViewDetailsIII.aspx?src $=$ TREATY\&mtdsg_no $=$ XXI $-6 \&$ chapter $=21 \&$ Temp $=$ mtdsg $3 \&$ clang $=$ _ en\#EndDec.

15. Valstybès žinios. 1999, No. 100-2893. 